SCJR 13, no. 1 (2018): 1-3

\title{
Franz Posset Johann Reuchlin (1455-1533): A Theological Biography
}

\author{
(Berlin / Boston: Walter de Gruyter, 2015), p. xxv + 917
}

\author{
LAWRENCE E. FRIZZELL \\ lawrence.frizzell@shu.edu \\ Seton Hall University, South Orange, NJ 07079
}

Franz Posset, the first scholar to make full use of the Johann Reuchlin archives, has presented in English a major study of the great German intellectual and lay theologian of the European Renaissance. There is a special focus on his publications and correspondence as a theologian; Posset is less interested in Reuchlin's work as a Doctor of Canon and Civil Law and diplomat.

Posset demonstrates that Reuchlin's theological interests shaped his views of Jews and Judaism. He was committed to the study of Scripture and learned Hebrew because he "wanted to find the original true meaning of the Word of God in the Scriptures" (p. 29). He was engaged in a "life-long search for the Hebrew truth of the Sacred Scriptures" (p. 29). His motivations were diverse. At the core "is his Catholic and biblical spirituality which includes a sense of justice and is decisively formed by his training in law, both secular and ecclesiastical" (p. 48).

These interests do not reflect an attempt to enhance the credibility of Judaism per se. Rather, he sought to appropriate Jewish knowledge into a Catholic context: "In his reading, Jewish books were instrumental in solidifying Catholic doctrine of Christ and the Holy Trinity" (p. 41). Nonetheless, these views had contemporary relevance. Reuchlin opposed "unlawful confiscation" of Jewish books and undertook to study not just biblical and rabbinic sources but Roman law concerning Jews. He insisted that Jews were to be treated with kindness (in fulfillment of the command to love one's neighbor), for they were not slaves but fellow citizens (pp. 46-47): "As a Catholic theologian, Reuchlin wanted to do justice to Jews as fellow human beings who happened to be of a different school of thought (Latin secta)" (p. 41).

Typical of his time, young Reuchlin journeyed far for his studies. He learned Greek and studied law at the universities of Paris, Orléans, Poitiers, and Basel. In 1482 he travelled to Rome as legal councilor in preparation for the foundation of the University of Tübingen, where he taught languages. His interests in Jews and Judaism grew over time. His first study of Hebrew began in 1486 with a Jewish 
teacher. During a visit to Florence in 1490, Reuchlin met Pico della Mirandola who introduced him to Kabbalah. During later trips to Italy, Reuchlin began to purchase Hebrew commentaries on the Bible and grammars.

Reuchlin took up the question of Jewish suffering. In his Missive from 1505 (an open letter, written in response to an unknown nobleman's question), he asked "Why are Jews in exile (misery) for so long?" Past scholars interpreted this as a typical polemical text of the time. However, this interpretation is rejected by Posset. Writing following the long reign (1440-93) of Emperor Frederick III (who expressed a "benevolent attitude toward the Jews" [p. 241]), Reuchlin's response was intended not to prompt a disputation but to support friendly discussions between Jews and Christians. It was therefore written as a series of "talking points."

He listed the following issues, which were likely commonly raised by Christians against Jews: 1.) The Jews' present exile is much longer than the Babylonian captivity, so the Jews' sin must have been greater. 2.) Misdeeds are punished to the third and fourth generation, but this exile has been much longer. 3.) Jews do not know the reason for their punishment because God has made them obdurate. He goes on to discuss the collective nature of the Jews' sins, above all, the sin of blasphemy originally committed by their forefathers against the true messiah. However, Posset argues, he wrote not to convert or attack Jews. While convinced of the truth of his Catholic faith, these are for "private conversations, to be used as 'talking points' but not as 'accusation points"” (p. 246).

About 1504, a Jew named Johann Pfefferkorn converted to Christianity and became associated with the Dominicans in Cologne. Because he was married he remained a layman, but he set as his goal the conversion of the Jews. In 1509 he published "The Enemy of the Jews" and the "Easter Booklet." Posset says he misunderstood Reuchlin's Missive and thought it was intended to promote conversion of Jews, leading him to quote from it in his works. Because of this, Reuchlin "clarified his position and his opposition to Pfefferkorn's claims" (p. 249). Pfefferkorn believed Reuchlin betrayed him, and there remained animosity between them throughout their lives. Their disputes dragged in many scholars on both sides, with some resorting to nasty ad hominem polemics.

Pfefferkorn was aided by the Dominicans of Cologne, with Prior Jacob van Hoogstraeten acting as an inquisitor and bringing charges against Reuchlin that eventually reached Rome. The ultimately successful charge against Reuchlin was not that he committed heresy but that his book Eye Glasses (written against Pfefferkorn's "Hand Mirror") was "scandalous and offensive to the pious ears of Christians" because it unduly favored the Jews (pp. 808, 875). During the prolonged debate about Reuchlin's work, there were unsavory attempts to influence Pope Leo X. (Ironically, though Pope Leo X criticized Reuchlin for seemingly favoring the Jews, he also granted Daniel Bomberg in Venice the privilege of printing the Talmud [p. 876].)

It seems that Jews were not involved in the dispute between Reuchlin and Pfefferkorn. However, Josel of Rosheim in Alsace (circa 1480-1554/5) was appointed by Maximilian to be the official speaker for all the German Jews. In his memoirs Josel praised Reuchlin's wisdom and the risks he took. He noted in par- 
ticular the seemingly miraculous efforts Reuchlin made to secure the return of confiscated Jewish books (p. 866).

Reuchlin interacted with many great humanists of his time, so the thorough research of Posset and the full indices should encourage researchers to consult this biography for details about both friends and enemies of this great scholar. Thirty-one illustrations (some in color) plus a chronology, bibliography, and indices of personal names and biblical references enhance the value of the book for those interested in European intellectual history of the time and in Reuchlin's contemporaries.

Posset received the Msgr. Harry C. Koenig Prize of the American Catholic Historical Association for this book. He deserves our congratulations and our gratitude for writing in English! 